Journal of Advanced Research in Business and Management Studies

\title{
Zakat and Tax Compliance Behaviour in Yemen: A Conceptual Study
}

\author{
Mohammed Mahdi Obaid ${ }^{1,2,}{ }^{*}$, Idawati Ibrahim ${ }^{1}$, Noraza Mat Udin ${ }^{1}$ \\ Tunku Puteri Intan Safinaz School of Accountancy, Universiti Utara Malaysia, 06010 Sintok, Kedah, Malaysia \\ Faculty of Administrative Sciences, Seiyun University, Seiyun, Hadhramout, Yemen
}

\section{ABSTRACT}

Zakat and tax revenues are important sources of income for financing public activities in many Muslim nations, including Yemen. However, the lack of tax compliance is undermining government efforts to raise the required revenue from these two critical sources, especially in Yemen. In Yemen, paying zakat to the government is a compulsory obligation for both individuals and corporate entities, and the same applies to conventional tax. Therefore, individuals and business establishments are reluctant as they consider paying both zakat and tax as double taxation on their income. Others perceive the way and manner by which zakat is imposed, collected, administered, and distributed, as unfair, which also causes dissatisfaction among the taxpayers. They therefore decide not to pay their zakat to the instituted authority. In light of this, the objectives of this study are: (i) to examine the different perspectives of Muslim scholars on conventional tax and zakat; and (ii) to examine previous findings on the effect of zakat and tax payment compliance behaviour of individual and corporate entities. To achieve the study's objectives, trust, attitude, and perceived service quality, are deemed as among the most influential determinants of zakat payment compliance behaviour among individuals and corporate entities. This study may have practical implications for the Yemeni government in terms of understanding the determinants of zakat and tax payment compliance behaviour of individuals and corporate entities. We recommend that future studies should empirically investigate the proposed concepts to determine the relationships between the determinants and tax compliance behaviour.

Keywords:

Tax, compliance behaviour, zakat payment, Yemen

Copyright @ 2020 PENERBIT AKADEMIA BARU - All rights reserved

\section{Introduction}

As a result of globalization and high demand for a better quality of life, tax revenue has become more critical to many governments around the world [1]. To provide public amenities, governments require steady and sustainable tax revenue. Taxes are a compulsory monetary contribution imposed and collected from individuals and corporate entities to be used by the government to provide public, social and infrastructural amenities in a country [2,3,4]. In Yemen, zakat and tax payment is compulsory and imposed on individuals and corporate businesses. Zakat and tax revenues are very crucial to the government as sources of income for public activities. According to Liana [3], zakat is a form of alms giving and is regarded as a religious rite which is obligatory in nature and ordained by divine Quranic revelation on all Muslims who have adequate wealth. Zakat is paid once a year under

\footnotetext{
* Corresponding author.

E-mail address: mohammedmahdiuum@gmail.com
} 
Islamic law on specified property, income, or wealth, and redistributed to specifically eight categories of people [5].

In Yemen, two authorities are responsible for collecting and administering tax revenues for the government. Zakat is collected and administered by the General Directorate of Zakat Obligation (GDZO), while conventional tax is collected and administered by the Yemeni Tax Authority (YTA) [6]. Thus, there is no direct administrative relationship between these two authorities. Both these authorities enforce and collect zakat and taxes from individuals and corporate taxpayers, and they are responsible for ensuring that taxpayers comply with the zakat and tax laws, respectively. Paying zakat to the government is compulsory for Yemeni individuals and corporate entities unlike other Muslim majority countries, such as Malaysia. In addition, both the GDZO and YTA are responsible for checking whether or not the taxpayers have paid their due zakat and taxes, in line with the provisions of the zakat and tax laws [7].

Under the conventional tax system, tax is collected from all eligible taxpayers. The tax revenue is used to pay for the running of the government machinery and for the provision of social and economic infrastructure and other amenities in the country. Zakat is collected from wealthy individuals and is compulsory [8]. In addition, zakat is an important element in the Islamic fiscal system, where it is both obligatory and compulsory. Based on this premise, zakat is imposed on Muslims only, while conventional tax is imposed on both Muslims and non-Muslims, who are residing in the country. Therefore, Muslims in Yemen must pay both conventional tax and zakat to the government [7]. However, there are various issues of low compliance in both the conventional and zakat payment systems, which adversely affect the country's revenue redistribution [8]. Since paying zakat is compulsory for individual and corporate taxpayers as it is with conventional taxes, taxpayers are reluctant to comply because some are of the opinion that it is a double tax on their income. AlBatly [9] reports that most taxpayers in Yemen perceive the payment of zakat to the government as an additional tax burden on their income over and above their conventional tax; thus, they attempt to not report their income, which leads to low tax compliance behaviour.

Previous studies on zakat compliance behaviour in Yemen have shown that there is low compliance [5]. Several reasons are attributed to the low zakat and tax payment compliance. These include individual attitude toward and perception of the tax authorities, lack of trust, and perceived service quality [10]. Other reasons include weak enforcement and different Islamic views on and perception of the process of collecting and managing the zakat monies [11,9]. Low zakat and tax payment compliance behaviour in the Arab region is very obvious due to social, political, economic, and often religion views and perceptions that influence the behaviour of individuals and corporate entities towards the authorities $[12,13,14]$. Therefore, the issue of zakat and tax payment compliance behaviour cuts across the region and has been identified as a main factor for the lack of development, especially in a country, like Yemen.

Despite the need of the Yemeni government for a steady flow of revenue to finance public activities, zakat and tax revenues are still not encouraging. According to Batly [9], the Yemeni government is facing continuous low zakat and tax revenue. This is compounded by poor enforcement strategies by the authorities, thus leaving government coffers in dire straits. Al-Ttaffi [7] also argued that the level of tax compliance is very low in Yemen, especially, from the perspective of individuals and corporate taxpayers. They feel the two payments (zakat and tax) are a form of double taxation that they are compelled to pay every year. This perception reduces the compliance level, thus denying the government adequate revenues required for public expenditure. Moreover, most Yemenis are living below the poverty line, and yet, their incomes are subjected to zakat. On the other hand, people who are wealthy and can pay zakat, do not comply with the zakat laws and pay 
their zakat to GDZO, because of lack of trust of the government. They prefer to distribute their zakat to the needy, specifically the eight categories of people recommended by Islamic law $[15,5]$.

Generally, the Yemeni government uses the zakat and tax revenues to provide the required amenities for the populace. However, low tax compliance behaviours have hindered the government's ability, and as such, the country lacks social and infrastructural development. Therefore, there is a need for further investigation on the relationship between the low tax compliance behaviour of corporate entities. In this regard, this paper reviews the literature and discusses the concept and the relationship between zakat and tax payment compliance behaviours of a specific entity, i.e., Small and Medium Enterprises (SMEs) from the Yemeni perspective. To the best of our knowledge, there is no empirical or conceptual study in Yemen that has investigated this perspective. Our study therefore attempts to fill the gap. The following sections of this study present a review of relevant and related literature, the different perspectives of Muslim scholars on conventional tax and zakat payment compliance, the main determinants of zakat and tax compliance, before providing a conclusion.

\section{Literature Review}

In the current study, two variables of zakat payment and SMEs' tax compliance behaviour are used. A review of these variables is made, to establish this study's conceptual framework.

\subsection{Concept of Tax Compliance and Related Theories}

Tax compliance is a multi-disciplinary concept that cuts across different disciplines, including sociology, accounting, economics, and psychology. Alm [16] argued that tax compliance behaviour is influenced by several factors. However, no single theory has been able to comprehensively describe the phenomenon of tax compliance behaviour $[16,71]$. Therefore, tax compliance behaviour among the taxpayers is explained via theories from all the disciplines mentioned above $[16,17,67]$.

Previous studies have shown that many factors influence tax and zakat payment compliance behaviour [72,71]. From a theoretical point of view, previous studies have discussed at length the problem of tax and zakat payment compliance and have concentrated on confirming that certain behavioural models can explain the determinants that could influence this behaviour, such as the deterrence theory [23], the socio-psychological theory, the social exchange theory and the social influence theory $[18,22]$.

Jackson and Milliron [17] and Alm [17] provided the reasons which affect taxpayers' attitude and compliance behaviour from social and psychological perspectives. Many theories have been postulated to help understand the behaviour of taxpayers more precisely. Specifically, as referred to above, the social exchange theory and social influence theory have been widely used. The theory of social exchange indicates that human interaction is created and calculated by the use of alternative comparisons based on empirical cost-benefit analysis. In this case, Blau [18] explained that the social exchange theory is based on the basic principle of social reciprocity. It is structured on the main assumption that human beings are moral, and that there is a difference between the cost of not doing anything. Additionally, the theory of social exchange suggests that human social activity is a product or performance of a practice-derived exchange. Cherry [19] argued that the justification for the swap is to mitigate costs or liabilities, and to increase profits or benefits. In addition, people weigh the probability of risks and benefits on their social relationship.

The social influence theory serves as a basis for understanding an individual's social behaviour that is related to some personal attributes. The theory shows how an individual's commitment 
influences the attitude toward a given behaviour. The theory states that compliance from an individual takes place when he/she believes in achieving positive feedback from another person or group of persons with a normative commitment. Human behaviour can also be explained by the relationship between attitude and the continuous common interaction with cognitive, behavioural, and environmental factors [20]. Therefore, the impact of human interaction plays a significant role in determining and understanding an individual's attitude toward human factors. Human beings mostly act in a rational manner by comparing the cost and benefits of any activity and are influenced by their surrounding environment and by different forces and factors $[21,68]$.

Furthermore, the economic approach to human behaviour indicates that people commit crimes because they know they will not be caught $[22,24]$. However, people will be deterred from committing any crime if they are aware that punishment is certain if they are caught [23]. Allingham and Sandmo [22] argued that the decision of taxpayers to comply or not to comply is a reasonable option in terms of ambiguity and risk, i.e., the taxpayers' decision is focused on the analysis of the expected compliance costs and the gain or advantage if they choose not to comply. Therefore, the entire rationality of the decision-making process is focused on the cost-benefit analysis and the prevailing environmental factors that form and influence an individual attitude's [24].

This makes the issue of low compliance very worrisome, especially to developing countries, such as Yemen, where the tax laws and enforcement agencies are weak, hence depriving the government of substantial tax revenue that is needed for nation building. According to Al-Ttaffi and Abdul-Jabbar [5], many views on taxes and tax compliance from the perspective of a Muslim country, such as Yemen, have been put forth. They argue that some taxpayers claim that taxes are forbidden, while others say it is valid in that the government has the right and the legal authority to impose and collect taxes in addition to zakat. Hence, these diverse views and opinions on taxes influence Yemeni's tax payment decision and tax compliance behaviour.

\subsection{The Concept of Zakat Payment}

The problem of zakat compliance is a long standing one and discussion in relation to tax is very rare [25]. Slam and Salma [69] stressed that zakat plays a significant role in the socio-economic development of Muslims. Kamil [26] examined the problems of payment of zakat by modifying the tax compliance factors. Zakat compliance refers to paying an amount in line with the rules and regulations set by the zakat authority. Zakat payment determinants can be identified by adapting the usual tax compliance behaviour variables in order to comprehend the taxpayers' behaviour. In addition, the rules and regulations enforced by the zakat authority need to be considered to decide whether or not citizens are deemed to be zakat abiding (compliant) and make payment based on zakat law.

Zakat payment is related to the decision of Muslims to comply with the zakat authority to pay a portion of their wealth, income, or property, based on the prescribed zakat laws, rules and regulations [25]. Paying zakat to the official zakat authority or unofficially to the needy, is a fulfilment of one of the fundamental pillars of Islam. Every Muslim is obliged to comply with the command and pay according to the Islamic principles and zakat law to attain satisfaction in this worldly life and the hereafter [27]. According to Barizah and Majid [28] and Sanep et al. [27], a few studies have examined payment of zakat via official channels or the zakat authority, especially in countries where Muslims constitute a substantial proportion of the population.

In general, Muslims are obliged to pay zakat to support the needy, as prescribed under the five pillars of Islam. In Yemen, it is the responsibility of individuals and corporate businesses to pay zakat to the zakat authority, for the government to distribute the monies to the people, especially the 
vulnerable $[5,71]$. Therefore, evading zakat payment to the zakat authority is viewed as an immoral act and a sabotage of the government's functions. Peerzade [29] argued that the zakat system in many Muslim nations is a more suitable option that combines human beliefs and religious actions, which encourages people to comply more easily compared to the conventional tax system. Therefore, if zakat institutions are strong with efficient and effective rules and regulations, there is a likelihood that zakat payment could replace conventional tax payment, and this may increase people's compliance behaviour.

From the Islamic perspective, both zakat and conventional income tax are very important for the development of a country, as well as the Muslim community. The zakat proceeds are redistributed to the needy among the Muslim community, whereas conventional tax is used to provide social and infrastructural development to the general public in the country [3]. In addition, Muslim taxpayers are aware of the importance of both conventional tax and zakat and how essential they are for the development of religion, individual citizens, and the country at large [30]. Individual religiosity level and its influence on zakat and tax compliance is very difficult to understand. In view of this, intention and perception of people are very important in any religion to explain and understand their level of commitment in complying with the prescribed laws. Therefore, from the Islamic religious perspective, people's work and activities are judged based on their intentions, as proposed by Prophet Muhammad (peace be upon him) [3]. According to Al-Ttaffi and Abdul-Jabbar [5], an individual's attitude towards religion, plays an important role in determining his or her attitude, such that people who perceive that tax is forbidden will behave negatively towards paying taxes. On the other hand, people who believe that paying tax is a duty of every citizen, irrespective of his or her religion, and that paying tax is compulsory for everyone, will be more compliant.

Generally, zakat payment (system) is perceived as the best tax system in most Muslim countries [5]. Thus, zakat is structured in a way that takes charge of the needs of all the eight categories of people and establishes a more stable and happy society [70].The zakat financial system is based on 'Shariah' (Islamic jurisprudents) rules, one of which is understanding zakat wealth or 'Nisab' (amount of zakat due on an individual's wealth) in imposing the amount of zakat, deducting of expenses and avoiding multiple assessment of the same person in a stipulated period [25]. Therefore, every Muslim with wealth that reaches 'Nisab', has a moral obligation to pay zakat to the authority and also to help the poor [31].

\section{Different Perspectives of Muslim Scholars on Conventional Tax and Zakat}

Muslims scholars have postulated many viewpoints and different opinions about taxes and zakat. Some view paying tax as forbidden, while others perceive it as a right and legitimate act of the government to impose and collect taxes from individuals under its jurisdiction for the purpose of financing public activities [5,12]. For instance, according to the Department of Zakat and Income Tax [32] in Saudi Arabia, only foreign individuals pay tax while Saudi nationals are not subjected to pay any income tax on their earnings. Instead, they pay zakat to the authority. From the business enterprise perspective, all foreign and Saudi nationals are subjected to pay both zakat and tax. In addition, it is also argued that companies operating in Saudi Arabia are obliged to pay both tax and zakat.

The collected zakat is distributed to individuals as mentioned in the Quran. These eligible individuals are known as 'asnaf' (eight categories of people mentioned in the holy Quran), while the tax imposed and collected is used to provide public services, like social and infrastructural development in the country [12]. The eight categories of people, known as 'asnaf' who are entitled to be given zakat according to the Quran are: the poor; the needy; those employed to administer the 
zakat funds; those whose hearts have been reconciled; those in bondage and in debt; those in a journey; and those in the cause of holy war (Quran, 9:60).

The Standing Committee for Scientific Research and Fatwa [33] of Saudi Arabia has issued a fatwa in respect of the Islamic view of tax on Muslims. The fatwa explains that in general, imposing and collecting tax and even working with the tax authority, is forbidden for Muslims, and for this reason, the government is not allowed to impose taxes on citizens. This fatwa clearly shows that imposing and collecting tax from Muslims by any government is prohibited and contrary to the Islamic view of the issuing body of this fatwa. In addition, this fatwa serves as a basis for tax non-compliance among taxpayers, especially in Muslim countries, where the perception is that tax payment based on such fatwa, is prohibited.

On the contrary, Al-Jibreen [34] argued that the issue of imposing taxes on Muslims is an issue related to individual diligence. He further stated that tax is compulsory on every Muslim under two instances: tax can be paid when the tax is representing zakat; and if the tax is in excess of the zakat needed to finance essential activities for the general public. On the other hand, imposing and collecting of tax is considered prohibited when the government imposes and collects the taxes on individuals unfairly, i.e., when the tax imposed and collected is unjust and biased. This situation could lead to tax being considered as prohibited, and vice versa.

In a related view, Hassan [35] summarized the perception of tax of some Islamic scholars, such as Al-Albani. The scholar supports the idea of prohibition of paying tax by Muslims. However, he provides certain conditions under which taxes are not prohibited, such as in situations when:

- Only the rich people are to be taxed and the accumulated tax will be fairly distributed;

- There is a budget deficit in the country; and

- Tax cannot be legally continued, and thus, can be imposed exceptionally where necessary.

Other scholars are of the view that tax could be imposed and collected from Muslims when the tax revenues are not used or spent on something that is against Islamic law and principles. This view is shared by Maududi [36], who stressed that the need for imposing and collecting tax revenues must be based on reality and not on presumptions. That means there should be a need for the tax revenue, i.e., when there is lack or inadequate sources of revenue for the government to carry out public amenities. This situation shows that the imposition of taxes does not mean replacing the tax with zakat payment. Shaltoot [37] and Abu-Zahra [38] argued that paying zakat is an act of Islamic worship, which is to be paid in any circumstance, i.e., whether needed or otherwise; while tax is imposed and collected only when the need arises.

Al-Omari [39] provided the verdicts of four major Islamic schools (Madzab) of jurisprudence with respect to imposing and collecting taxes. These four schools are Maliki, Hanafi, Shafi'i, and Hanbali, and the views on tax are as follows:

- Maliki School supports the government in imposing and collecting tax in special circumstances, where the government needs such revenues for public welfare.

- Hanafi School accepts the imposition of tax on individuals provided there is a need for collecting the taxes and based on some prevailing activities.

- Shafi'i School allows and recognizes the legality of imposing and collecting taxes only on the rich people for the benefit of public services. 
- Hanbali School gives the authority to impose tax when the collected taxes are to be used for supporting Islamic teaching and propagation.

In addition to the above views, if tax is imposed fairly on Muslims, then tax evasion is prohibited, but if the imposed tax is not fair, then it is permissible and legally right to evade such tax [40]. In summary, the Islamic perspective on tax imposition and collection could be classified into three as follows:

- Absolutely prohibited [33].

- Absolutely acceptable [41].

- $\quad$ Acceptable under certain conditions $[36,39,35,34]$

In Yemen, paying zakat and complying with the tax payment is compulsory. Any effort by taxpayers to avoid paying taxes and zakat is considered an offence. Both GDZO and YTA impose and collect zakat and tax, respectively, to fund public activities, infrastructural development and other social wellbeing of the populace in the country. But the issue of low compliance is undermining the efforts of the government. Many previous studies in Yemen support this argument $[8,51,10]$.

\section{Zakat Payment and Tax Compliance Behaviour}

The relevant literature shows that zakat payment has a significant impact on different issues, such as savings and trust in the government $[42,3,43,44,45]$. However, the relationship between payment of zakat and tax compliance behaviour is still not very clear. In other words, there is lack of studies that have investigated the relationships between these two variables, i.e., zakat payment and tax compliance behaviour. In some countries, like Malaysia, there is a link between zakat and tax, as the amount of zakat paid is rebated from the tax due [46]. Such regulation may motivate taxpayers to comply with tax rules, and thus, the level of tax compliance improves. However, this relief is not applicable in other countries, including Yemen. According to Obaid et al. [71], Yemeni corporate entities are required to pay the full amount of both zakat and conventional tax.

Liana [3] investigated the pattern of distribution of individual income tax and zakat payment among Muslim taxpayers, and the criteria that motivate their tax and zakat payment behaviour. The study found that most Muslim taxpayers tend to pay more zakat compared to the sum which Islamic law requires them to pay. For Muslim taxpayers, the zakat rebate is an opportunity to avoid paying income tax or reduce income tax contribution. In another study, Mohdali and Pope [43] investigated the influence of religiosity on taxpayers' compliance attitude in Malaysia. The findings indicate that religiosity has a significantly positive impact on voluntary tax compliance, signifying that strong religious beliefs and values held by many Malaysians, strongly influence their charity given behaviour. Ghani et al. [42] indicated that the organizations in charge of zakat should focus on increasing their efficiency in order to restore trust and confidence among payers of zakat. In brief, the relationship between zakat and tax payment compliance still needs further investigation. In Yemen, the GDZO has different regulations from YTA. As mentioned earlier, there is no direct departmental link between the tax and zakat authorities [71]. Consequently, each authority receives sums owed by people quite separately from the other, and there is therefore no financial overlap between them. The YTA collects the maximum taxes from taxpayers, regardless of whether or not the taxpayer has also paid zakat, and whether the amount of zakat is higher or lower than the amount of tax collected $[7,71]$. 


\section{Determinants of Tax Compliance and Zakat}

From the literature review on tax compliance and zakat, there are different variables that influence zakat. These factors are mostly adapted from studies on tax compliance behaviour and its variables. However, Kamil [26] and Noor and Saad [25] both argued that it is very difficult to determine the variables that influence zakat payment behaviour without taking into account the tax compliance variables. Moreover, there is need to adapt these variables because zakat has different peculiarities in terms of rate, frequency of paying, items for which the zakat is paid, origin and source of the wealth in terms of lawful (halal) and unlawful (haram) income/wealth and those to whom the zakat is to be given. Therefore, to determine the level of zakat payment compliance, one has to consider adapting some of the attributes of tax compliance behaviour and incorporate them into the realm of zakat in order to understand the factors that influence individual zakat payment behaviour. As earlier discussed in section 3 above, there are conflicting views from the Islamic scholars' perspectives in terms of zakat payment and tax compliance behaviours. Therefore, this study considers trust, attitude, and perceived service quality as determinants of zakat compliance behaviour among Yemeni SMEs.

\subsection{Trust}

Trust is a multifaceted concept that has been studied in many areas, such as in schools, information technology services, accounting, and retail and banking industries $[47,48,49,50]$. In the area of zakat, trust is used as a core premise in determining the relationship between various contexts, which has been found to be positive in boosting the confidence level of the general public or customers in an organization [25]. As such, trust is viewed as a belief in which someone will act as anticipated in a socially responsible manner, even in the absence of enforcement and will fulfil the anticipation of that somebody who trusted them [51,25].

In some zakat studies, trust is used to understand the extent to which individuals trust the zakat authority when paying their zakat. For instance, in the Malaysian state of Selangor, Hairunnizam and Sanep [52] examined the factors that influence the trust level in zakat distribution. Their result indicates that the level of trust among zakat payers of the zakat authority is based on three primary factors, which are: zakat collection process, zakat distribution, and the corporate image of the zakat authority. Htay and Salman [53] also posited that paying zakat to the zakat authority depends on the level of confidence and trust zakat payers have on the zakat authority in collecting and distributing the collected zakat. This means that trust is a very influential factor that determines the level of zakat payment compliance by individual zakat payers.

This also shows that trust is a very important and significant factor to understand the factors that influence zakat payers to comply [25]. Additionally, it indicates that the zakat authority will receive more zakat when the payers have confidence in the processes of collecting and distributing their zakat [54]. If the zakat institutions perform well, then they will generate trust among people, but when they perform poorly, it will create distrust and lack of confidence, which will result in scepticism among the zakat payers [52]. This finally may lead to low zakat payment due to lack of trust between zakat payers and the zakat institution.

\subsection{Attitude}

Individual behaviour of Muslims toward paying zakat and tax is determined by their attitude and intention. In this context, empirical evidences exist which show that attitude is one of the factors 
that determines behaviour toward certain laws, rules and regulations, such as paying zakat and tax from the Islamic religious perspective [5]. Mas'ud et al. [55] argued that an individual's tax compliance is determined and influenced by his or her intention and attitude toward tax laws. Hence, a Muslim person's attitude and intention toward zakat payment are likely to be influenced by intentions which could determine his or her attitude and behaviour toward the zakat authority.

Generally, Muslim individuals' views on paying their zakat to the authority depend on the laws that guide the zakat authority in collecting zakat from them. For instance, in Yemen, it is compulsory for a Muslim to pay his or her zakat to the GDZO as ordered by the government. However, some Yemeni individuals and corporate entities do not pay their zakat to the authority directly. Rather, they pay to the needy Muslims due to their different perception of zakat and negative attitude toward the authority $[5,6]$. Therefore, non-payment of zakat to the zakat authority by some Yemeni citizens and corporate entities in any way is regarded as violation of the rules and regulations, and it is punishable in the relevant court of law.

Unlike in Yemen, in Malaysia, Muslims are encouraged to pay their zakat to their respective State zakat authority, but in case someone gives it directly to the needy Muslims, he or she will not be charged for his or her action or be liable to punishment in a court of law [56,3].Therefore, attitude and intention are very important and influential determinants of an individual's zakat compliance behaviour. An individual's religion and perception play a significant role in determining his or her attitude and behaviour towards zakat and tax payment compliance [30]. This is obvious because belief influences attitude and attitude determines behaviour.

\subsection{Perceived Service Quality}

Service quality is one of the key determinants of human behaviour in both zakat and tax literature [30]. According to Noor and Saad [25], perceived quality of the zakat payers of services provided by the zakat authority, is one of the important and influential factors for understanding zakat compliance behaviour among Muslims. Parasuraman et al. [57] argued that service quality is determined by the differences in customers' expectations and the actual service received. This means when the customer receives services based on his or her expectations, it will increase his or her loyalty and adherence to the service provider and the law.

Studies regarding perceived service quality as a factor that determines behaviour, cuts across many fields, such as banking services [59,60]; healthcare services [61]; management and marketing services [62]; religious tourism, i.e., Hajj services [63]; and technology and self-services [64]. According to Noor and Saad [25], there are very few studies on the role of service quality of zakat institutions in determining zakat payment behaviour. Therefore, it is imperative to use service quality provided by zakat institutions to determine Muslims' zakat compliance behaviour. In addition, it has also been argued that the extent of service quality is a measure for determining zakat payers' adherence and whether or not they are satisfied with services provided by the zakat institutions [26].

Service quality is also used as a factor to understand taxpayers' behaviour. McGee et al. [65] argued that service quality is positively related to tax compliance behaviour. Philip and Sandall [66] also opined that perceived service quality is linked to taxpayers' compliance behaviour. They stated that taxpayers would comply with tax payments provided they are satisfied with the services they receive in return for their collected taxes. In other words, if the government is not providing or meeting the taxpayers' expectations in terms of services provided, then compliance will be low [67]. Therefore, both zakat and tax compliance behaviours could be influenced by the quality of service individuals receive from the administering body in respect of their payment. 


\section{Methodology}

This study is a cross-sectional, and correlational study. The population will consist of approximately 27,796 SMEs in the manufacturing sector, as reported by the Yemeni Ministry of Industry and Trade [73]. Measurements to be used will be adapted from previous studies. This study's survey tool is a questionnaire based on items adapted from previous tax compliance studies. This research will follow Miller [74], who found the five-point Likert scale to be the most suitable and reliable scale, to measure the questionnaire items.

\section{Conceptual Framework}

The study focuses on the evolvement of a framework for the manufacturing sector SMEs listed under Yemeni's Ministry of Industry and Trade. Based on the review, a new framework has emerged that conceptualizes the interlinks between zakat payment and SMEs' tax compliance behaviour in Yemen. This framework considers three determinants of zakat payment and tax compliance, which are: trust, attitude, and perceived service quality. The conceptual framework is as in Figure 1 below.

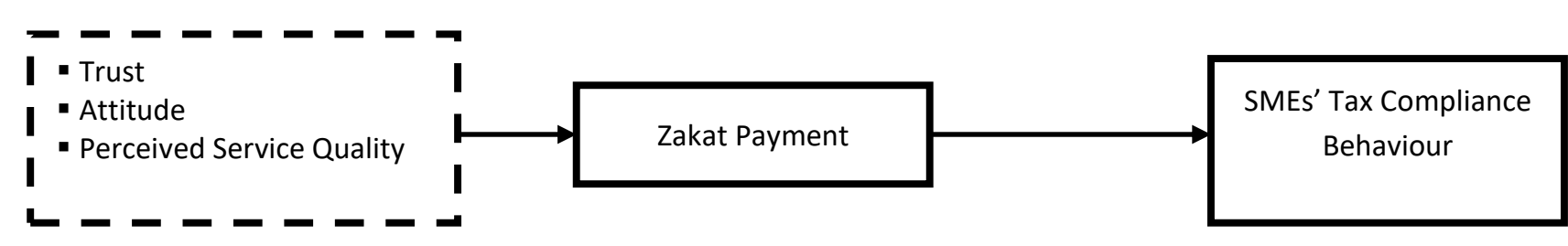

Fig. 1. The Conceptual framework of the Study

\section{Conclusions}

In general, there are different views among Islamic scholars, jurists and interpretivists about the imposition on and collection of tax from Muslims. Some of the scholars have argued that tax is completely forbidden, or permissible, or acceptable under certain conditions. These differences in the perceptions and opinions among scholars can be the key factors that determine the attitude of Muslims and in understanding their tax compliance behaviour. For this reason, zakat payment and tax compliance behaviours among Muslims depend on their intention and attitude towards the Islamic views, and often, trust in the authorities. Therefore, this study reviews literature on zakat and tax compliance in Yemen. According to the Arab Centre for Studies and Economic Media [15], the political situation in Yemen is one of the reasons for the poor social and infrastructural development in the country. It is also a result of long-standing inadequate funds for the government, which is attributed to zakat and tax non-compliance of the Yemeni citizens. This situation has put the country into difficulties and about $80 \%$ of the populace are still living below the poverty line. This has resulted in, many Yemenis not paying their zakat and complying with tax obligations. There are other reasons, such as lack of trust, taxpayers' attitude and poor service quality by the government in return for the collected zakat and taxes. Understanding the factors that could determine zakat and taxpayers' behaviour is therefore very essential for improving zakat and tax compliance behaviour among individuals and corporate entities. Therefore, future studies could empirically explore the relationship between the identified factors for zakat and tax non-compliance behaviour. This will 
provide additional evidence on how these factors influence the behaviour of individuals and corporate entities.

\section{Acknowledgement}

Deepest appreciation goes to the Department of Accounting, Faculty of Administrative Sciences, Seiyun University, Hadhramout, Yemen, for providing the scholarship to one of the authors to undertake this study. Sincere appreciation also attributed to the Tunku Puteri Intan Safinaz, School of Accountancy, Universiti Utara Malaysia, Malaysia.

\section{References}

[1] Umar, Mohammed Abdullahi, Chek Derashid, and Idawati Ibrahim. "What Is Wrong with the Fiscal Social Contract of Taxation in Developing Countries? A Dialogue with Self-Employed Business Owners in Nigeria." Sage Open 7, no. 4 (2017): 2158244017745114. https://doi.org/10.1177/2158244017745114

[2] Gurama, Zakariya'U., Muzainah Mansor, and Abdurrahman Adamu Pantamee. "Tax evasion and Nigeria tax system: an overview." Research Journal of Finance and Accounting 6, no. 8 (2015): 202-211.

[3] Liana, Puteri Nur. "A Preliminary Study o Norms and Motivations Towards Zakat and Income Tax Payment by Muslim Tax Payer." International Academic Journal of Accounting and Financial Management 5, no. 3 (2018): 118123.

[4] Aidil, A. A. M., and A. M. Hussin. "The Comparison between Zakat (Islamic Concept of Taxation) and Income Tax: Perception of Academician in the State of Perak. Bangkok Thailand: The 2013 IBEA." In International Conference on Business, Economics and Accounting, pp. 20-23. 2013.

[5] Al-Ttaffi, Lutfi Hassen Ali, and Hijattullah Abdul Jabbar. "Does Muslim view on tax influence compliance behaviour?." (2015): 347-353.

[6] Bin-Nashwan, Saeed Awadh, Hijattulah Abdul-Jabbar, Saliza Abdul Aziz, and Alhassan Haladu. "Zakah compliance behavior among entrepreneurs: economic factors approach." International Journal of Ethics and Systems (2020). https://doi.org/10.1108/IJOES-09-2019-0145

[7] Al-Ttaffi, Lutfi Hassen Ali. "Determinants of tax non-compliance behaviour of Yemeni SMEs: a moderating role of Islamic religious perspective." PhD diss., Universiti Utara Malaysia, 2017.

[8] Obaid, S. (2008). Minorities in the Arab World. Albalagh Journal, Yemen Sana'a, 6(5), 43-36.

[9] Al-Batly, A. "Removal government fuel subsides." Journal of Experimental Psychology: Friedrich Ebert Stiftung, Sana'a 1, no. 8 (2014): 1-45.

[10] Al-Ttaffi, L., and Hijattulah Abdul-Jabbar. "Geopolitics and its implications for tax administration." In International Conference on Government \& Public Affair (ICOGPA), Sintok, Malaysia, pp. 05-06. 2016.

[11] Al-Shamahi, A. (2015). Yemen returns full circle as Houthis end fuel subsidies. New Arab. Retrieved from https://www.alaraby.co.uk/english/news/2015/7/28/yemenreturns-fullcircle-as-houthis-end-fuel-subsidies

[12] Al-Ayyan, S. "The literature of conflict between Zakat and tax in Saudi Arabia." Journal of Islamic research 43 (2007): 111-128.

[13] Al-Rabeae, F. "Failure of the unity between the republics of Yemen: a scientific approach under unity theories." Madar centre for Studies and Research. Palestine (2014).

[14] Arab Centre for Studies and Economic Media (2015). Cairo Middle East Studies, Annual Reports.

[15] Al-Yasani, A. "An economic study of the impact of economic reform on the agricultural sector in Yemen." PhD diss., Doctoral dissertation, College of Commerce, Al-Nailin University, Sudan, 2005.

[16] Alm, James. "Tax compliance and administration." Public Administration and Public Policy 72 (1999): $741-768$. https://doi.org/10.4324/9781315093161-30

[17] Jackson, Betty R., and Valerie C. Milliron. "Tax compliance research: Findings, problems, and prospects." Journal of accounting literature 5, no. 1 (1986): 125-165.

[18] Blau, Peter. Exchange and power in social life. Routledge, 2017. https://doi.org/10.4324/9780203792643

[19] Ekeh, Peter P. Social exchange theory: The two traditions. London: Heinemann, 1974.

[20] Bandura, A. (1977). Self-efficacy toward a unified theory of behavioural change. Psychological Review, 84(20, 191. https://doi.org/10.1037/0033-295X.84.2.191

[21] Brooks, Neil. "The challenge of tax compliance." Tax Administration: Facing the Challenge of the Future, Prospect Media, St Leonards (1998): 7-33. 
[22] Allingham, Michael G., and Agnar Sandmo. "Income tax evasion: A theoretical analysis." Journal of public economics 1, no. 3-4 (1972): 323-338. https://doi.org/10.1016/0047-2727(72)90010-2

[23] Becker, Gary S. "Crime and punishment: An economic approach." In The economic dimensions of crime, pp. 13-68. Palgrave Macmillan, London, 1968. https://doi.org/10.1007/978-1-349-62853-7 2

[24] Obaid, Mohammed Mahdi, Idawati Ibrahim, and Noraza Mat Udin. "Determinants of SMEs tax compliance in Yemen: A pilot investigation." IOSR Journal of Humanities and Social Science (IOSRJHSS) 15, no. 1 (2020): 64-75.

[25] Noor, Azura Mohd, and Ram Al Jaffri Saad. "The mediating effect of trust on the relationship between attitude and perceived service quality towards compliance behavior of zakah." International Journal of Economics and Financial Issues 6, no. 7S (2016).

[26] Kamil, Md. "Gelagat kepatuhan zakat pendapatan gaji di kalangan kakitangan awam persekutuan Negeri Kedah." PhD diss., Universiti Utara Malaysia, 2002.

[27] Sanep, A., Ghani, M.N.N., Zulkifli, D. (2011). Tax-based modeling of zakat compliance, (Permodalan Kepatuhan Zakat Berasaskan Cukai). Jurnal Ekonomi Malaysia, 24, 101-108.

[28] Bakar, Nur Barizah Abu, and Hafiz Majdi Abdul Rashid. "Motivations of paying zakat on income: Evidence from Malaysia." International Journal of Economics and Finance 2, no. 3 (2010): 76-84. https://doi.org/10.5539/ijef.v2n3p76

[29] Peerzade, Sayed. "Towards self-enforcing Islamic tax system: an alternative to current approaches." Journal of King Abdulaziz University: Islamic Economics 18, no. 1 (2005). https://doi.org/10.4197/islec.18-1.1

[30] Ali, R. M. \& Pope, J. (2014). The influence of religiosity on taxpayers' compliance attitudes: Empirical evidence from a mixed-methods study in Malaysia. Accounting Research Journal, 27(1), 71-91. https://doi.org/10.1108/ARJ-08-2013-0061

[31] McGee, Robert W. "The ethics of tax evasion and trade protectionism from an Islamic perspective." Commentaries on Law \& Public Policy 1 (1997).

[32] The Saudi Department of Zakat \& Income Tax (2015). Retrieved from ttp://dzit.gov.sa/collection-of-tax.

[33] Standing Committee for Scientific Research \& Fatwa (1994). Islamic Question and Answer. retrieved from http://www.islam-qa.com/en/ref/108105/tax.

[34] Al-Jibreen, A. (2012). "Ask and answer". Al-muslim website. Retrived from http://almoslim.net/taxonomy/term/196?page=5.

[35] Hassan, A. (2010). "Islamic ask and answer". Kul Alsalfyen forum. Retrieved from http://audio. Islamweb.net/audio/index.php?page=fullcontent\&auditoid=109246-44k.

[36] Maududi, A. (2005). Islamic feqh forum, researcher's personal website. Retrieved from http://www.islamnafeqh.com/News/Newslt...ewsltem ID=1181.

[37] Shaltoot, M. (2000). Islamic feqh, researcher's personal website. Retrieved from http://islamfeqh.com/News/NewsIt...ewsltem ID=1181.

[38] Abu-Zahra, M. (1998). Islamic feqh forum, researcher's personal website. Retrieved from http://www.islamnafeqh.com/News/Newslt...ewsltem ID=1181.

[39] Al-Omari, E. (2009). Noor Islam forum, researcher's personal website. Retrieved from http://www.nourislamna.com/vb/t11727.html.

[40] Fatwa Center (2012). Islamic website specializes in issuing fatwas under the supervision and management of the members of the Arab Society for Fatwa and Research. Retrieved from http://fatwa.islamweb.net/fatwa/index.php?page=fatwaadvancesearch

[41] Nadzri, Farah Aida Ahmad, Abdur Rahman, and Nomrah Rashidah \& Omar. "Zakat and poverty alleviation: Roles of zakat institutions in Malaysia." International Journal of Arts and Commerce 1, no. 7 (2012): 61-72.

[42] Ghani, Erlane K., Asmah Abdul Aziz, Sakinah Mohamed Tajularifin, and Nahla Samargandi. "Effect of Board Management and Governmental Model on Zakat Payers' Trust on Zakat Institutions." Global Journal AlThaqafah (2018): 73-86.

https://doi.org/10.7187/GJATSI2018-05

[43] Freudenberg, Brett, Kerrie Sadiq, Raihana Mohdali, and Jeff Pope. "The influence of religiosity on taxpayers' compliance attitudes." Accounting Research Journal (2014).

[44] Wahid, H., and S. Ahmad. "Factors influencing the confidence level of the zakat distribution: study on the Muslim community in Selangor." Jurnal Ekonomi Malaysia 48, no. 2 (2014): 41-50.

https://doi.org/10.17576/jem-2014-4802-04 
[45] Bidin, Zainol, Mohd Zainudin Othman, and Farah Mastura Noor Azman. "Zakat compliance intention behavior on saving among Universiti Utara Malaysia's staff." In Proceeding of the International Conference on Social Science Research, pp. 145-155. 2013.

[46] Khamis, Mohd Rahim, Rohani Mohd, Arifin Md Salleh, and Abdol Samad Nawi. "Do religious practices influence compliance behaviour of business zakat among SMEs?." Journal of Emerging Economies \& Islamic Research 2, no. 2 (2014).

[47] Alabede, James O. "An investigation of factors influencing taxpayers' compliance behaviour: Evidence from Nigeria." PhD diss., Universiti Utara Malaysia, 2012.

[48] Gupta, Manish, and Yln Kumar. "Justice and employee engagement." Asia-Pacific Journal of Business Administration (2015). https://doi.org/10.1108/APJBA-04-2014-0048

[49] Min, L. I., Dingtao Zhao, and Yan Yu. "TOE drivers for cloud transformation: direct or trust-mediated?." Asia Pacific Journal of Marketing and Logistics (2015).

[50] Fatma, Mobin, Zillur Rahman, and Imran Khan. "Building company reputation and brand equity through CSR: the mediating role of trust." International Journal of Bank Marketing (2015). https://doi.org/10.1108/IJBM-11-2014-0166

[51] Nunkoo, Robin, and Haywantee Ramkissoon. "Power, trust, social exchange and community support." Annals of Tourism Research 39, no. 2 (2012): 997-1023.

https://doi.org/10.1016/i.annals.2011.11.017

[52] Wahid, Hairunnizam, and Sanep Ahmad. "Faktor Mempengaruhi Tahap Keyakinan Agihan Zakat: Kajian Terhadap Masyarakat Islam di Selangor." Jurnal Ekonomi Malaysia 48, no. 2 (2014): 41-50. https://doi.org/10.17576/jem-2014-4802-04

[53] Htay, Sheila Nu Nu, and Syed Ahmed Salman. "Proposed best practices of financial information disclosure for zakat institutions: A case study of Malaysia." World Applied Sciences Journal 30, no. 30 A (2014): 288-294.

[54] Mustafa, Murtala Oladimeji Abioye, Muslim Har Sani Mohamad, and Muhammad Akhyar Adnan. "Antecedents of zakat payers' trust in an emerging zakat sector: an exploratory study." Journal of Islamic Accounting and Business Research (2013). https://doi.org/10.1108/17590811311314267

[55] Mas'ud, Abdulsalam, Almustapha Alhaji Aliyu, E. J. Gambo, A. A. Al-Qudah, and N. Al Sharari. "Tax rate and tax compliance in Africa." European Journal of Accounting Auditing and Finance Research 2, no. 3 (2014): 22-30.

[56] Shariff, Anita Md, W. N. H. W. Jusoh, Norudin Mansor, and Kamaruzaman Jusoff. "A robust zakah system: Towards a progressive socio-economic development in Malaysia." Middle-East Journal of Scientific Research 7, no. 4 (2011): 550-554.

[57] Parasuraman, Anantharanthan, Valarie A. Zeithaml, and Leonard L. Berry. "A conceptual model of service quality and its implications for future research." Journal of marketing 49, no. 4 (1985): 41-50. https://doi.org/10.1177/002224298504900403

[58] Choudhury, Koushiki. "Service quality and customers' behavioural intentions." Asia Pacific Journal of Marketing and Logistics (2015). https://doi.org/10.1108/APJML-02-2015-0025

[59] Islam, Rafikul, Selim Ahmed, and Dzuljastri Abdul Razak. "Identifying the gaps between customer expectations and perceptions on service quality dimensions of Islamic banks in Malaysia." International Journal of Quality and Service Sciences (2015).

https://doi.org/10.1108/IJQSS-12-2014-0053

[60] Shafei, Ingy, Jan Auke Walburg, and Ahmed F. Taher. "Healthcare service quality: what really matters to the female patient?." International journal of pharmaceutical and healthcare marketing (2015). https://doi.org/10.1108/IJPHM-05-2014-0028

[61] Sundbo, Jon. "From service quality to experience-and back again?." International Journal of Quality and Service Sciences (2015). https://doi.org/10.1108/IJQSS-01-2015-0009

[62] Eid, Riyad. "Towards a high-quality religious tourism marketing: The case of Hajj service in Saudi Arabia." Tourism Analysis 17, no. 4 (2012): 509-522. https://doi.org/10.3727/108354212X13473157390849

[63] Boon-itt, Sakun. "Managing self-service technology service quality to enhance e-satisfaction." International Journal of Quality and Service Sciences (2015). https://doi.org/10.1108/IJQSS-01-2015-0013

[64] McGee, Robert W., Serkan Benk, Halil Yıldırım, and Murat Kayıkçı. "The ethics of tax evasion: A study of Turkish tax practitioner opinion." European Journal of Social Sciences 18, no. 3 (2011): 468-480. 
[65] Everest-Phillips, M., and R. Sandall. "Linking business tax reform with governance: how to measure success Washington." DC: World Bank (2008).

[66] Murphy, Kristina. Procedural justice and the regulation of tax compliance behaviour: the moderating role of personal norms. No. paper0731. International Center for Public Policy, Andrew Young School of Policy Studies, Georgia State University, 2007.

[67] Obaid, Mohammed Mahdi, Idawati Ibrahim, and Noraza Mat Udin. "An Investigation of the Determinants of Tax Compliance Among Yemeni Manufacturing SMEs Using the Fisher Model." International Journal of Psychosocial Rehabilitation 24, no. 04 (2020). https://doi.org/10.37200/IJPR/V24I4/PR201289

[68] Alm, James. "What motivates tax compliance?." Journal of Economic Surveys 33, no. 2 (2019): 353-388. https://doi.org/10.1111/joes.12272

[69] Islam, Mohammad Saiful, and Umme Salma. "THE MANAGEMENT OF ZAKAT BY CENTER FOR ZAKAT MANAGEMENT (CZM): A MALAYSIAN EXPERIENCE." Journal website: journal. zakatkedah. com. my 2, no. 1 (2020).

[70] MAJEED, Muhammad Tariq. "REAL WELlBEING OF THE UMMAH AND ECONOMIC PERFORMANCE: Islamic Perspectives and Empirical Evidence Muhammad Tariq MAJEED." Pakistan Journal of Applied Economics 29, no. 1 (2019): 1-31.

[71] Obaid, Mohammed Mahdi, Idawati Ibrahim, and Noraza Mat Udin. "The Moderating Role of Subsidy Removal on Factors Influencing SMEs Tax Compliance in Yemen."

[72] Alm, James, and Benno Torgler. "Do ethics matter? Tax compliance and morality." Journal of Business Ethics 101, no. 4 (2011): 635-651. https://doi.org/10.1007/s10551-011-0761-9

[73] Abdullah, Ahmed, Brychan Thomas, Lyndon Murphy, and Eoin Plant. "An investigation of the benefits and barriers of e-business adoption activities in Yemeni SMEs." Strategic Change 27, no. 3 (2018): 195-208. https://doi.org/10.1002/isc.2195

[74] Miller, E. (1991). Men at risk. Jamaica Publishing House. 